\title{
Baroreceptor sensitivity and diabetes mellitus
}

\author{
Olumide Olatubosun Rowaiye ${ }^{1}$, Ewa Anita Jankowska ${ }^{2,3}$, Beata Ponikowska ${ }^{1}$ \\ ${ }^{1}$ Department of Physiology, Wroclaw Medical University, Wroclaw, Poland \\ ${ }^{2}$ Department of Heart Diseases, Wroclaw Medical University, Wroclaw, Poland \\ ${ }^{3}$ Center for Heart Diseases, Military Hospital, Wroclaw, Poland
}

\begin{abstract}
Diabetes mellitus (DM) is a disease of increasing incidence and prevalence. Arterial baroreceptors are stretch-sensitive receptors, which in a reflex manner are involved in the homeostatic control of arterial blood pressure. Diabetic subjects have depressed baroreflex sensitivity (BRS), although the exact pathomechanisms are unclear. In this review, we discuss the features, clinical and prognostic implications of reduced BRS for diabetic patients and the potential involvement of cardiovascular autonomic neuropathy and atherosclerosis. Finally, we demonstrate evidence on interventions (e.g. pioglitazone, alpha-lipoic acid, leptin, fluvastatin, physical training etc.) which could improve BRS and ameliorate cardiovascular autonomic dysfunction in diabetic patients. (Cardiol J 2013; 20, 5: 453-463)
\end{abstract}

Key words: arterial baroreceptors, autonomic dysfunction, baroreflex sensitivity, cardiovascular autonomic neuropathy, diabetes mellitus

\section{Introduction}

Diabetes mellitus (DM) is a metabolic disease with increasing incidence and prevalence. In DM, there is an alteration in the cardiovascular reflex response and one of the key elements of this alteration is the impaired response from arterial baroreceptors. The deterioration in the baroreflex function in diabetic patients, its features, clinical and prognostic consequences and the potential for its reversal are discussed in this article.

However, the following important keywords need to be defined in order to afford the reader a better understanding of the concepts presented in this article.

Baroreflex sensitivity (BRS). An autonomic assessment parameter which provides insight on the autonomic regulation of cardiovascular function. BRS measures the reflex-mediated change in R-R interval produced by a change in the systolic blood pressure (BP).
Autonomic dysfunction. A malfunction or disease of the autonomic nervous system. DM is a common cause of autonomic dysfunction. Impaired BRS is indicative of autonomic dysfunction.

Cardiovascular autonomic neuropathy (CAN). A form of diabetic autonomic neuropathy (DAN) characterized by cardiovascular autonomic dysfunction resulting from damage to the autonomic nerve fibers innervating the heart and blood vessels. Impaired BRS is an element of CAN.

\section{Physiology of arterial baroreceptors}

The reflex response from baroreceptors (baroreflex) is one of the body's mechanisms for the homeostatic control of arterial BP and the maintenance of the optimal perfusion of critical organs such as the brain, heart, etc. Arterial baroreceptors are stretch-sensitive receptors found in the arterial walls (localized mainly in the carotid sinus of the carotid arteries and in the walls of the aortic arch) [1].

Address for correspondence: Olumide O. Rowaiye, MD, Department of Physiology, Wroclaw Medical University, ul. T. Chałubińskiego 10, 50-368 Wrocław, Poland, tel: +48 7178400 91, fax: +48 717840092 , e-mail: olurowe@yahoo.com

Received: 13.09.2012 Accepted: 25.03.2013 
Arterial baroreceptors are innervated and remain under the reflex neural control. Afferent fibers from the carotid and aortic baroreceptors pass via the glossopharyngeal and the vagal nerves into the nucleus tractus solitarius in the medullary area of the brainstem $[1,2]$. The efferent fibers pass via the parasympathetic and sympathetic arms of the autonomic nervous system to the heart and blood vessels [2], as the baroreceptor reflex consists of two main components namely the cardiac and the vascular components $[2,3]$. The baroreflex system for the control of arterial pressure is based on a negative feedback mechanism and is the most rapid of all the body's BP control mechanisms [1].

An increase in systolic BP (SBP) stretches the arterial baroreceptors and they respond by increasing their rate of action potential generation which is then transmitted to the brain stem. Appropriate compensatory responses are initiated by the cardiovascular control center in the brainstem in order to decrease SBP. This is achieved via an increase in the vagal (parasympathetic) outflow and a decrease in the sympathetic outflow to the heart and blood vessels. The resultant effect is a decrease in heart rate (bradycardia), cardiac contractility, stroke volume, peripheral vascular resistance and venous return [1, 4].

\section{Methods of assessing baroreflex function in humans}

The functional integrity of arterial baroreceptors can be assessed using various BRS assessments. The rationale behind the BRS testing is to see how a spontaneous or provoked (using either vasoactive drugs or certain maneuvers) change in SBP brings about a reflex-mediated change in RR intervals [4-6].

In the vasoactive drug (pharmacological) method, the drug that has been traditionally used for the BRS assessment is the alpha-adrenergic agonist phenylephrine, and the test is designated as a phenylephrine test (BRS-Phe). Injecting phenylephrine (a vasoconstrictor) brings about an increase in SBP, which induces a reflex-mediated change in RR intervals [4, 5, 7]. As there is a linear association between an increase in SBP and the subsequent increase in RR intervals, the BRS-Phe is expressed as a slope of the regression line linking changes in SBP and RR intervals $[4,5]$. Vasodilators like sodium nitroprusside or nitroglycerin can also be used to assess BRS $[4,7]$. However, the BRS-Phe remains the gold standard for BRS evaluation.
The Valsalva maneuver is done by either expiring against a closed glottis [4] or blowing (exhaling) continuously into a closed system for about $12 \mathrm{~s}$ at a pressure of at least $40 \mathrm{~mm} \mathrm{Hg}$ [5]. The BRS can then be estimated from the linear regression analysis of the SBP and the RR interval changes during the phase IV of this maneuver (phase IV is characterized by BP overshoot due to the effects of prevailing vasoconstriction and the normalization of cardiac output and venous return) [4].

The neck chamber method involves the application of positive or negative pneumatic pressure to the neck region in order to specifically stimulate or deactivate the carotid baroreceptors in that region $[3,4]$. The carotid BRS can then be obtained from the slope of the regression of the $\mathrm{RR}$ intervals on the neck pressure values [4].

In the controlled breathing method (BRS-CtrBr), the examined subject performs regular inspirations and expirations for a certain period of time (e.g. 3-5 $\mathrm{min}$ ) at a constant rate of e.g. 6 breaths per minute $(0.1 \mathrm{~Hz})$ [7, 8]. The ratio of the amplitude of RR intervals oscillations to the amplitude of SBP oscillations is another measure of BRS [7].

BRS can also be assessed using continuous recording and relating $\mathrm{BP}$ and $\mathrm{RR}$ intervals during different maneuvers that involve change in body position, e.g. orthostasis (where the examined subject stands upright throughout the test period [7]); the squatting test (here, the examined subject stands for $3 \mathrm{~min}$ at the beginning of the test, then squats down for $1 \mathrm{~min}$, and finally stands again for another $1 \mathrm{~min}[9,10])$; and the tilt-table method (where both the head-up tilting and downward tilting techniques can be used [7]).

In the microneurography method, the slope of the relationship between muscle sympathetic nerve activity and diastolic $\mathrm{BP}$ is used to assess the BRS [7].

Spontaneous BRS can be obtained using the sequence and spectral analysis methods [4-6]. The sequence method (BRS-Seq) defines BRS as the slope of the linear regression of three or more consecutive beats (in which progressive rise/fall in SBP are accompanied by progressive lengthening/shortening of RR intervals) $[4,6]$. In the spectral analysis method, BRS assessment is based on the relationship (in terms of gain, phase and coherence) between SBP and RR intervals in the low frequency and high frequency bands [4-6]. 
In healthy subjects, numerous factors influence BRS, such as: age, gender, genetic factors, baseline heart rate, baseline BP, fatness and body weight, hormone status, arterial stiffness, some drugs and physical activity [11-15].

BRS also increases in the presence of parasympathetic dominance and decreases in the presence of sympathetic dominance [5].

\section{Diabetes mellitus, diabetic autonomic neuropathy, and baroreflex impairment}

Impairment in the baroreflex function (i.e. reduced BRS) has been demonstrated in subjects with DM, both in experimental models using streptozotocin (STZ)-induced diabetic rats [16-18] and in diabetic patients [19-21]. However, some authors did not confirm such observations [22-25].

Diabetic patients quite commonly develop the so-called diabetic autonomic neuropathy (DAN). Its exact origin remains unknown, however, some authors consider this pathology as metabolic and ischemic nerve injuries due to chronic hyperglycemia [26]. Hyperglycemia-induced changes cause a decrease in endoneurial circulation (reduced blood flow to the nerves) resulting in ischemia and hypoxia $[26,27]$. The attendant effect of endoneurial hypoxia is impaired axonal transport [26, 27] and finally axonal atrophy [26]. Furthermore, hyperglycemia causes an activation of the polyol pathway with the enzyme aldose reductase serving as a catalyst; this leads to the accumulation of sorbitol and fructose in the nerves thereby resulting in intracellular deficiency of myoinositol in the nerve tissues and changes in the structural nerve proteins [26, 27]. Hyperglycemia also causes oxidative stress with increased production of oxygen free radicals [26-28] which results in tissue damage [27]. In some patients, immunological and inflammatory processes can play a role in the development of neuropathy [27, 28]. Other factors leading to neuronal damage in diabetic neuropathy include decrease in nerve growth factors, and disorders in the metabolism of essential fatty acids [27, 28].

Although DAN can affect nerves innervating most body organs, its effects on the structures innervating the cardiovascular system seem to be prominent and clinically relevant $[6,27,28]$. In CAN, there occurs cardiovascular autonomic dysfunction resulting from injury to the autonomic nerve fibers innervating the cardiovascular system. The clinical manifestations of CAN [6, 27-29] include: exercise intolerance, resting tachycardia, orthostatic hypotension, silent (painless) myocar- dial ischemia, intra-/perioperative cardiovascular lability, orthostatic tachycardia and bradycardia syndromes, increased mortality risk.

CAN seems to be associated with an increased risk for major cardiovascular events such as myocardial infarction (MI) and stroke [30-32]. Methods used in the diagnosis and evaluation of CAN include:

- heart rate variability (HRV) [6];

- the standardized (conventional) battery of autonomic function tests proposed by Ewing et al. [33] (such as heart rate [HR] response to Valsalva manuever, HR response to deep breathing, HR response to orthostasis, BP response to orthostasis, $\mathrm{BP}$ response to sustained handgrip);

- spontaneous BRS [6];

- cardiac radionuclide imaging [6].

Both HRV [5, 6, 27, 28] and BRS [19, 20] are reduced in CAN patients. HRV as an assessment tool is one of the earliest indicators of CAN $[5,6$, $27,28]$; its drawback however lies in the fact that its parameters are more difficult to interpret in comparison to other noninvasive autonomic tests mentioned above [5]. Cardiac radionuclide imaging as an assessment tool is not feasible for quick and routine evaluation of patients in the outpatient setting. Spontaneous BRS is one of the most promising but perhaps less-commonly-used tools for assessing cardiovascular autonomic dysfunction in diabetic patients. Comparative studies involving the use of both spontaneous BRS and conventional autonomic function tests in the diagnosis of CAN have demonstrated the following:

- spontaneous BRS was capable of detecting autonomic dysfunction earlier than conventional autonomic function tests [19, 34];

- spontaneous BRS showed greater sensitivity and specificity in the detection of autonomic dysfunction than conventional autonomic function tests [20,35].

\section{Pathophysiological theories of diminished BRS in diabetes mellitus}

Although the exact pathomechanisms leading to reduced BRS in DM remain unclear, some evidence has linked the reduced BRS to diabetes-induced changes in the autonomic nervous system and its regulation of cardiovascular functions [11, 33, 36-40]. These changes which can occur at both the central and peripheral (afferent and efferent) levels of the baroreflex circuit (as shown in Fig. 1 and Table 1) lead to autonomic dysfunction (as indicated by a diminished BRS). 


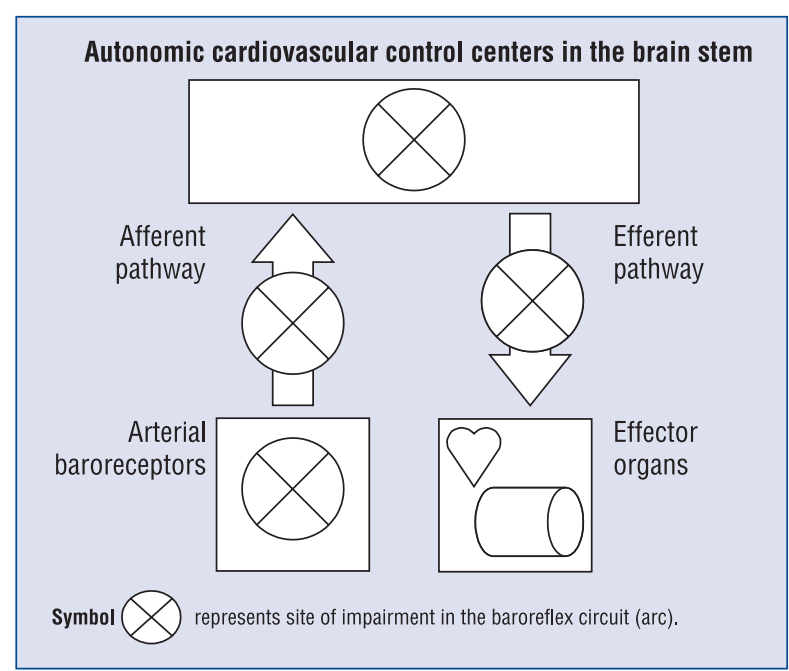

Figure 1. Impairments occurring at the different levels of the baroreflex circuit in diabetic patients.
Atherosclerosis may also contribute to BRS impairment at the baroreceptor level of the baroreflex circuit (Fig. 1, Table 1). Diabetes is a known risk factor for atherosclerosis [41]. As a matter of fact, atherosclerosis is both premature and accelerated in diabetic patients [41, 42]. Carotid atherosclerosis has been associated with depressed BRS [43-46]. In another study in type 2 DM patients, carotid atherosclerosis was linked to impaired BRS and CAN [47].

\section{Features, clinical and prognostic consequences of diminished BRS in diabetes mellitus}

Diabetic patients who have diminished BRS are characterized by the following features (see also section a of Table 2). They demonstrate:

Table 1. Diabetes-induced changes in the baroreflex circuit associated with diminished baroreflex sensitivity (BRS).

\begin{tabular}{|c|c|c|c|}
\hline $\begin{array}{l}\text { Level of baroreflex } \\
\text { circuit }\end{array}$ & $\begin{array}{l}\text { Author and } \\
\text { reference }\end{array}$ & $\begin{array}{l}\text { Specific location of } \\
\text { impairment associated } \\
\text { with diminished BRS }\end{array}$ & $\begin{array}{l}\text { Brief description of } \\
\text { impairment associated } \\
\text { with diminished BRS }\end{array}$ \\
\hline Arterial baroreceptors & $\begin{array}{l}\text { Gianaros } \\
\text { et al. [43] }\end{array}$ & $\begin{array}{l}\text { Human carotid bulb } \\
\text { (abundant in baroreceptors) }\end{array}$ & $\begin{array}{l}\text { Increased IMT (a sign of subcli- } \\
\text { nical atherosclerosis) associated } \\
\text { with } \downarrow \text { BRS }\end{array}$ \\
\hline \multirow[t]{3}{*}{ Afferent pathways } & Clarke et al. [48] & $\begin{array}{l}\text { Carotid sinus nerve (a branch } \\
\text { of the glossopharyngeal) } \\
\text { in diabetic rats }\end{array}$ & $\begin{array}{l}\text { Diabetes-induced axonal and } \\
\text { intramyelinic edema }\end{array}$ \\
\hline & Fazan et al. [49] & $\begin{array}{l}\text { Aortic depressor nerve } \\
\text { (an afferent branch of the vagus) } \\
\text { in STZ-induced diabetic rats }\end{array}$ & $\begin{array}{l}\text { Diabetes-induced axonal atrophy } \\
\text { of the nerve }\end{array}$ \\
\hline & Li et al. [50-52] & NG in STZ-induced diabetic rats & $\begin{array}{l}\downarrow \text { cell excitability of the aortic } \\
\text { baroreceptor neurons in the NG } \\
\text { resulting from overactivation of } \\
\text { both the angiotensin II-NADPH } \\
\text { oxidase superoxide signal } \\
\text { pathway and the HCN channels }\end{array}$ \\
\hline \multirow[t]{2}{*}{ Efferent pathways } & $\begin{array}{l}\text { Gottsäter et al. } \\
\text { [47] }\end{array}$ & $\begin{array}{l}\text { Parasympathetic efferents in } \\
\text { type } 2 \text { DM patients with CAN }\end{array}$ & $\begin{array}{l}\text { Abnormal } E / I \text { ratio indicating } \\
\text { structural damage in parasympa- } \\
\text { thetic efferents }\end{array}$ \\
\hline & $\begin{array}{l}\text { Eckberg et al. } \\
{[53]}\end{array}$ & $\begin{array}{l}\text { Sympathetic efferents in DM } \\
\text { patients }\end{array}$ & $\begin{array}{l}\text { Abnormal sympathetic responses } \\
\text { indicative of structural damages in } \\
\text { the sympathetic efferent pathway }\end{array}$ \\
\hline \multirow{2}{*}{$\begin{array}{l}\text { Autonomic cardiova- } \\
\text { scular control centers } \\
\text { in the brainstem }\end{array}$} & Chen et al. [39] & NTS in STZ-induced diabetic rats & $\begin{array}{l}\text { Diabetes-induced impairment in } \\
\text { the NTS }\end{array}$ \\
\hline & Yan et al. [40] & NA in diabetic mice & $\begin{array}{l}\text { Diabetes-induced structural } \\
\text { changes (reduction in the number } \\
\text { of cardiac motor neurons in NA); } \\
\text { diabetes induced functional } \\
\text { changes (reduced regulation } \\
\text { of heart rate by NA) }\end{array}$ \\
\hline
\end{tabular}

CAN - cardiovascular autonomic neuropathy; DM — diabetes mellitus; E/I — expiration/inspiration; HCN — hyperpolarization-activated cyclic nucleotide-gated; IMT — intima-media thickness; NA — nucleus ambiguous; NG — nodose ganglia; NTS — nucleus tractus solitarii; STZ - streptozotocin 
Table 2. Features, clinical and prognostic consequences, prognostic determinants of diminished baroreflex sensitivity (BRS) in diabetes mellitus (DM).

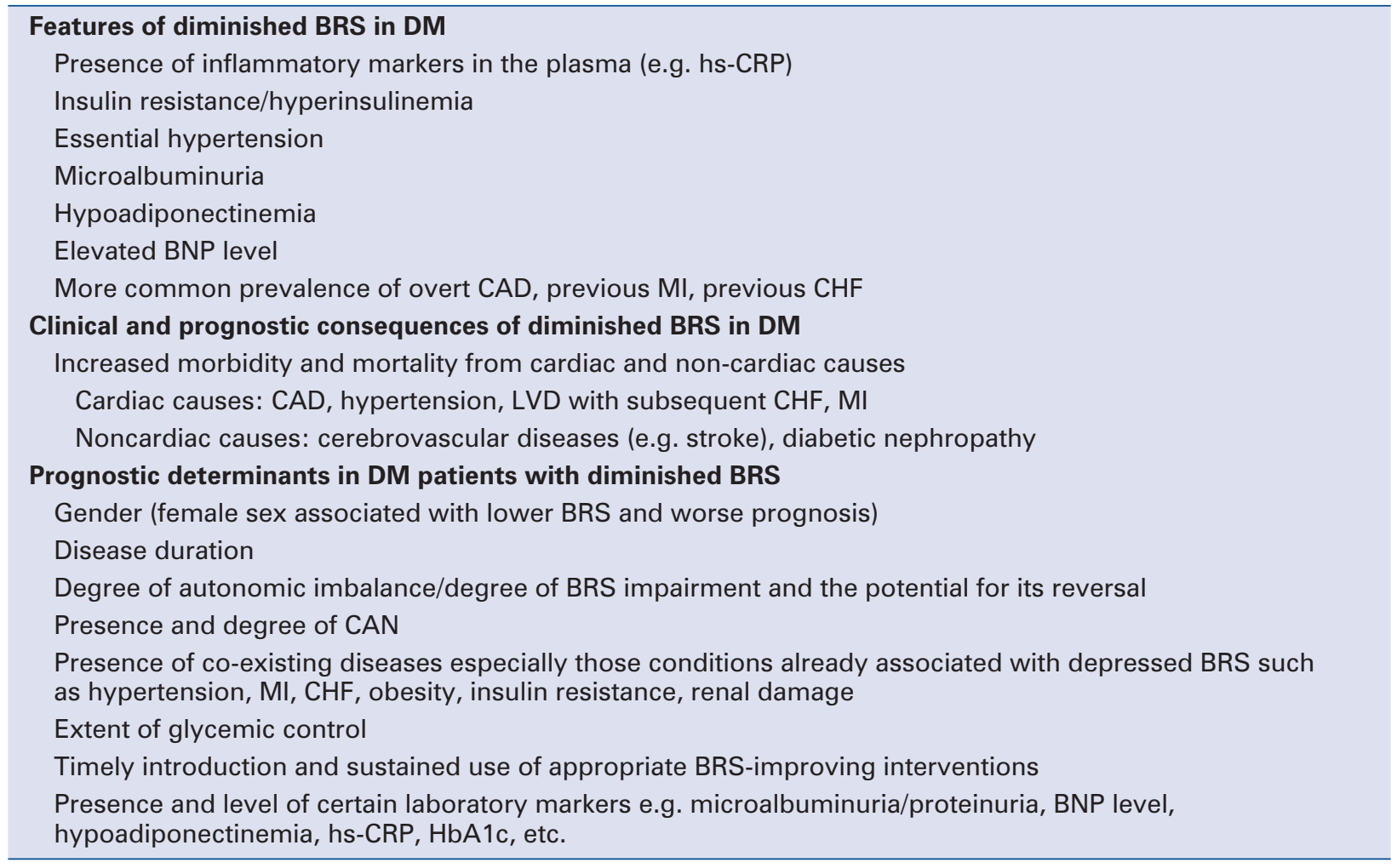

BNP — brain natriuretic peptide; CAD — coronary artery disease; CAN — cardiovascular autonomic neuropathy; CHF — congestive heart failure; hs-CRP — high sensitivity C-reactive protein; HbA1c — glycated hemoglobin; LVD — left ventricular dysfunction; MI — myocardial infarction

- The presence of low-grade inflammation (higher levels of plasma high-sensitivity C-reactive protein (hsCRP) [54]: In type 2 DM patients, increased plasma levels of hsCRP have been associated with depressed cardiovascular autonomic function as indicated by diminished BRS [54]. Higher plasma levels of CRP have also been linked to insulin resistance, obesity (increased body mass index) and the development of type $2 \mathrm{DM}$, thereby suggesting the role of an underlying inflammatory process in the etiopathogenesis of diabetes [55-57].

- Insulin resistance/hyperinsulinemia: Studies show that DM patients with insulin resistance/hyperinsulinemia have a reduced BRS $[54,58-60]$. This association can perhaps be explained by the findings that insulin causes sympathetic nervous system activation [61, 62].

- Essential hypertension [59]: Hypertension occurs more often in diabetic patients (especially in type $2 \mathrm{DM}$ ) than in nondiabetic patients with most hypertensive diabetic patients having essential hypertension [63].
Impaired BRS could contribute to the development of hypertension in DM [64]. Also both essential hypertension and type $2 \mathrm{DM}$ exert a combined synergistic effect that diminishes BRS [59]. Hypertension in diabetic patients has also been attributed to the actions of hyperinsulinemia in stimulating the sympathetic nervous system $[61,65]$.

- Renal damage as evidenced by microalbuminuria: In microalbuminuric type $1 \mathrm{DM}$ patients, BRS was found to be depressed [66]. Studies in type $2 \mathrm{DM}$ patients showed that the presence of microalbuminuria was characterized by both insulin resistance and cardiovascular autonomic dysfunction (as indicated by a diminished BRS, lower myocardial 123I-metaiodobenzylguanidine [MIBG] uptake, etc.) [58]. In addition, studies conducted in elderly type $2 \mathrm{DM}$ patients showed that CAN and arterial $\mathrm{BP}$ were independently associated with microalbuminuria [67]. From the results of all these studies, one could hypothesize that sympathetic overactivity is perhaps the pathophysiological link between microalbumi- 
nuria and diminished BRS. Microalbuminuria is an independent risk factor for cardiovascular events such as MI, stroke, cardiovascular death and congestive heart failure (CHF) in both diabetic and non-diabetic subjects [68].

- Hypoadiponectinemia (decreased level of plasma adiponectin): Adiponectins are proteins secreted by adipose tissues; , they circulate in great amounts in the human plasma and play a role in glucose regulation (by reducing plasma glucose and improving insulin sensitivity in both healthy and diabetic subjects) and also in the catabolism of fatty acids [69]. Hypoadiponectinemia has been associated with insulin resistant states (such as type $2 \mathrm{DM}$ and obesity), hypertension and vascular atherogenesis [60, 69-71]. In studies in type 2 DM patients, hypoadiponectinemia was found to be associated with increased cardiac sympathetic activity and therefore with a diminished BRS [60].

- The presence of neurohormonal activation (high levels of plasma B-type natriuretic peptide (BNP) [72]: BNP, a cardiac neurohormone can help identify diabetic patients at increased risk of developing left ventricular abnormalities [73]. Diminished BRS has been linked to left ventricular abnormalities (as indicated by an increased left ventricular mass index) in DM patients [74]. It has also been demonstrated that BNP can serve as a prognostic tool in DM patients, helping to identify those at increased risk of mortality from cardiovascular and other causes [75].

- More common prevalence of overt coronary artery disease (as indicated by the need for revascularization) [76], previous $\mathrm{MI}$ and previous $\mathrm{CHF}$ : BRS has been shown to be depressed in post-MI subjects [77-79].

\section{Clinical and prognostic consequences of} diminished BRS (see Table 2)

Diminished BRS in DM is associated with an increased risk of morbidity and mortality from cardiac and non-cardiac causes. One study using the BRS-Phe method in 184 patients (who had type $2 \mathrm{DM}$ without structural heart diseases or any other severe complications) with a mean follow-up period of 4.7 years, linked diminished BRS to incidences of nonfatal MI, CHF, need for coronary revascularization, stroke and cardiovascular deaths [76]. The link between depressed BRS and renal disease (as indicated by microalbuminuria) has been discussed earlier.
In the Hoorn study [80] involving hundreds of subjects who had either DM, or hypertension or a history of cardiovascular disease with a 9 year follow-up period, it was shown that the mortality risk from cardiac and other causes was roughly twice greater in those who had DM and concomitant impairment in autonomic function (as evidenced by diminished BRS).

The prognostic determinants in DM patients with diminished BRS are outlined in Table 2. Female diabetic patients have been shown to have lower BRS and worse prognosis than their male counterparts [81]. Also, there exists a negative correlation between the disease duration and the BRS in diabetic patients [82]. Studies in DM patients have demonstrated that the degree of autonomic (sympathovagal) imbalance determines the extent of BRS impairment [82]. In addition, the extent of BRS impairment is also a determinant factor as a more depressed BRS has been associated with a poorer prognosis $[81,83]$. Furthermore, as stated in an earlier section, CAN is associated with a more significantly depressed BRS [20] and therefore as can be expected a poorer prognosis. Also from a therapeutic point of view, abnormal autonomic tests (BRS inclusive) in patients with advanced CAN are less amenable to reversal by interventional modalities as will be discussed in the next section. Since BRS is reduced in CHF, hypertension, insulin resistance, obesity, and after MI as earlier stated, the co-existence of these disease conditions in a DM patient with an already depressed BRS increases the likelihood of an unfavorable prognosis. Improved glycemic control slows the progression of DM [84] and should therefore improve prognosis in such patients. BRS has also been correlated with HbA1c level [82].

\section{Interventions improving BRS in patients with diabetes mellitus}

Studies in experimental animal models and in diabetic patients have demonstrated an improved BRS following the use of pharmacological and nonpharmacological interventions (Table 3 ). Some other interventions (Table 4) have also been shown to be useful in ameliorating cardiovascular autonomic dysfunction in DM.

\section{Clinical perspective on interventional modalities}

Of all the interventional modalities listed in Table 3, physical (exercise) training seems to be the most effective in improving BRS. The importance of regular and sustained exercise regimen 
Table 3. Interventions improving baroreflexsensitivity (BRS) in diabetic subjects.

\begin{tabular}{|c|c|c|c|c|}
\hline Specific intervention & $\begin{array}{l}\text { Study subjects } \\
\text { with references }\end{array}$ & $\begin{array}{l}\text { Duration of use of } \\
\text { intervention }\end{array}$ & $\begin{array}{l}\text { Major mechanism(s) } \\
\text { by which interven- } \\
\text { tion improved BRS }\end{array}$ & $\begin{array}{l}\text { Added advantage(s) } \\
\text { of intervention }\end{array}$ \\
\hline $\begin{array}{l}\text { Pioglitazone } \\
\text { (a thiazolidinedione) }\end{array}$ & $\begin{array}{l}\text { Type } 2 \text { DM } \\
\text { patients with } \\
\text { recent MI [85] }\end{array}$ & $\begin{array}{l}12 \text { weeks of } \\
\text { treatment }\end{array}$ & $\begin{array}{l}\text { Sympathoinhibition } \\
\text { resulting from the } \\
\text { effects of the drug } \\
\text { in decreasing insu- } \\
\text { lin resistance }\end{array}$ & $\begin{array}{l}\uparrow \text { level of plasma } \\
\text { adiponectin; } \\
\downarrow \text { incidence of fatal } \\
\text { and nonfatal MI }\end{array}$ \\
\hline ALA-an antioxidant & $\begin{array}{l}\text { STZ-induced } \\
\text { diabetic rats } \\
{[86]}\end{array}$ & $\begin{array}{l}\text { At least } 4 \text { weeks } \\
\text { treatment }\end{array}$ & $\begin{array}{l}\downarrow \text { oxidative stress; } \\
\text { reversal of DM-in- } \\
\text { duced deficit in } \\
\text { c-Fos-ir neurons } \\
\text { in the NTS }\end{array}$ & Refer to Table 4 \\
\hline $\begin{array}{l}\text { Leptin (an adipose } \\
\text { tissue derived } \\
\text { hormone) }\end{array}$ & $\begin{array}{l}\text { Short-term } \\
\text { STZ-induced } \\
\text { diabetic rats } \\
{[87]}\end{array}$ & $\begin{array}{l}7 \text { days of continuous } \\
\text { ICV infusion }\end{array}$ & $\begin{array}{l}\text { Actions of leptin on } \\
\text { the central nervous } \\
\text { system to induce } \\
\text { euglycemia }\end{array}$ & $\begin{array}{l}\text { Normalization of } \\
\text { plasma glucose; } \\
\text { reversal of diabetes- } \\
\text {-induced hyperphagia }\end{array}$ \\
\hline $\begin{array}{l}\text { Fluvastatin (HMG- } \\
\text {-CoA reductase } \\
\text { inhibitor) }\end{array}$ & $\begin{array}{l}\text { STZ-induced } \\
\text { type } 1 \text { diabetic } \\
\text { rats [88] }\end{array}$ & $\begin{array}{l}30 \text { days of } \\
\text { treatment }\end{array}$ & $\begin{array}{l}\text { Still to be determi- } \\
\text { ned, but perhaps } \\
\text { connected to the } \\
\text { effects of statins in } \\
\text { up-regulating the } \\
\text { expression of nNOS } \\
\text { in the RVLM }\end{array}$ & $\begin{array}{l}\text { Antilipemic, antioxi- } \\
\text { dative, antiatheroge } \\
\text {-nic and antithrom- } \\
\text { botic effects of the } \\
\text { drug; improvement } \\
\text { of impaired cardiac } \\
\text { function }\end{array}$ \\
\hline $\begin{array}{l}\text { Lacidipine (a long- } \\
\text {-acting calcium } \\
\text { channel blocker) }\end{array}$ & $\begin{array}{l}\text { Hypertensive } \\
\text { type } 2 \text { DM pa- } \\
\text { tients [89] }\end{array}$ & $\begin{array}{l}4 \text { weeks of once } \\
\text { daily treatment }\end{array}$ & $\downarrow \mathrm{MABP}$ and BPV & \\
\hline $\begin{array}{l}\text { Breathing exercise } \\
\text { (slow, deep, con- } \\
\text { trolled breaths, } \\
6 \text { breaths } / \mathrm{min} \text { ) }\end{array}$ & $\begin{array}{l}\text { Type } 1 \text { DM pa- } \\
\text { tients with va- } \\
\text { rying duration } \\
\text { of disease [90] }\end{array}$ & $\begin{array}{l}\text { Short (one-time } \\
\text { maneuver during } \\
\text { which BP and ECG } \\
\text { were recorded }\end{array}$ & $\begin{array}{l}\text { Perhaps due to im- } \\
\text { proved autonomic } \\
\text { function resulting } \\
\text { from the maneuver }\end{array}$ & $\begin{array}{l}\uparrow \text { BRS in most patients } \\
\text { studied (irrespective } \\
\text { of disease duration), } \\
\text { except in those with } \\
\text { definite CAN }\end{array}$ \\
\hline \multirow[t]{4}{*}{$\begin{array}{l}\text { Physical training } \\
\text { (exercise) }\end{array}$} & $\begin{array}{l}\text { STZ-induced } \\
\text { diabetic rats } \\
{[91]}\end{array}$ & $\begin{array}{l}\text { Single session of } \\
\text { aerobic exercise }\end{array}$ & $\begin{array}{l}\text { Not investigated in } \\
\text { study }\end{array}$ & - \\
\hline & $\begin{array}{l}\text { STZ-induced } \\
\text { diabetic rats } \\
{[92]}\end{array}$ & $\begin{array}{l}10 \text { weeks of tre- } \\
\text { admill exercise } \\
\text { training }\end{array}$ & $\begin{array}{l}\uparrow \text { baroreflex tachy- } \\
\text { cardic and brady- } \\
\text { cardic responses }\end{array}$ & $\begin{array}{l}\uparrow \text { chemoreflex } \\
\text { sensitivity }\end{array}$ \\
\hline & $\begin{array}{l}\text { Type } 2 \text { DM } \\
\text { patients [93] }\end{array}$ & $\begin{array}{l}12 \text { months (of twice } \\
\text { weekly enduran- } \\
\text { ce and muscle } \\
\text { strength training } \\
\text { sessions) }\end{array}$ & $\begin{array}{l}\text { May be connected } \\
\text { to exercise-induced } \\
\text { improvements in } \\
\text { endothelial function } \\
\text { and endoneurial } \\
\text { circulation }\end{array}$ & $\begin{array}{l}\uparrow \text { glycemic control; } \\
\uparrow \text { exercise capacity; } \\
\uparrow \text { muscle strength }\end{array}$ \\
\hline & $\begin{array}{l}\text { Type } 2 \text { DM pa- } \\
\text { tients with con- } \\
\text { comitant } \\
\text { hypertension } \\
\text { and hyperchole- } \\
\text { sterolemia [94] }\end{array}$ & $\begin{array}{l}3 \text { months (of thrice } \\
\text { weekly aerobic } \\
\text { exercise) }\end{array}$ & $\begin{array}{l}\text { Not investigated in } \\
\text { study }\end{array}$ & - \\
\hline
\end{tabular}

ALA — alpha-lipoic acid; BP — blood pressure; BPV — blood pressure variability; CAN — cardiovascular autonomic neuropathy; c-Fos-ir - c-Fos-immunoreactive; DM — diabetes mellitus; ECG - electrocardiography; HMG-CoA - 3-hydroxy-3-methylglutaryl coenzyme A; ICV - intracerebroventricular; MABP — mean arterial blood pressure; MI — myocardial infarction; nNOS - neuronal nitric oxide synthase; NTS - nucleus tractussolitarius; RVLM - rostral ventrolateral medulla; STZ - streptozotocin

in the management of the cardiovascular risks associated with DM cannot be overemphasized. Regular exercise has been shown to improve HRV parameters in patients with CAN (Table 4) with a deterioration of those parameters within weeks of complete exercise withdrawal [109]. 
Table 4. Interventions ameliorating cardiovascular autonomic dysfunction in diabetes mellitus (as indicated by other autonomic markers such as heart rate variability [HRV]).

\begin{tabular}{|c|c|c|c|}
\hline $\begin{array}{l}\text { Interven- } \\
\text { tion }\end{array}$ & $\begin{array}{l}\text { Study type and/or } \\
\text { subjects involved } \\
\text { with reference(s) }\end{array}$ & $\begin{array}{l}\text { Duration of use/duration } \\
\text { of study of intervention }\end{array}$ & Effect(s) of intervention \\
\hline \multirow[t]{4}{*}{ Insulin } & $\begin{array}{l}\text { Type } 2 \text { DM patients on oral } \\
\text { antidiabetic drugs [95] }\end{array}$ & $\begin{array}{l}4 \text { months follow-up of daily } \\
\text { insulin administration }\end{array}$ & $\uparrow \mathrm{HRV}$ \\
\hline & $\begin{array}{l}\text { Type } 1 \text { DM patients with } \\
\text { varying degrees of CAN [96] }\end{array}$ & $\begin{array}{l}12 \text { months of intensive } \\
\text { insulin therapy }\end{array}$ & $\begin{array}{l}\uparrow \mathrm{HRV} \text { in patients with early } \\
\text { CAN }\end{array}$ \\
\hline & $\begin{array}{l}\text { Type } 1 \text { DM patients who } \\
\text { received intensive insulin } \\
\text { therapy - DCCT study [97] }\end{array}$ & $\begin{array}{l}\text { Average follow-up of } \\
6.5 \text { years }\end{array}$ & $\begin{array}{l}\text { Intensive insulin therapy } \\
\text { slowed down the incidence } \\
\text { and progression of abnormal } \\
\text { autonomic tests }\end{array}$ \\
\hline & $\begin{array}{l}14 \text { years follow-up study } \\
\text { in former DCCT intensive } \\
\text { insulin therapy patients [98] }\end{array}$ & & $\begin{array}{l}\downarrow \text { incidence of CAN in former } \\
\text { intensive insulin patients for } \\
\text { even up to } 14 \text { years after } \\
\text { DCCT completion }\end{array}$ \\
\hline Metformin & $\begin{array}{l}\text { Obese type } 2 \text { DM patients } \\
\text { [99] }\end{array}$ & $\begin{array}{l}4 \text { months of metformin } \\
+ \text { diet }\end{array}$ & $\begin{array}{l}\uparrow \text { cardiac sympathovagal } \\
\text { balance (as indicated by } \\
\uparrow \text { HRV parameters) }\end{array}$ \\
\hline $\begin{array}{l}\text { Quinapril } \\
\text { (ACEI) }\end{array}$ & $\begin{array}{l}\text { DM patients with and } \\
\text { without DAN [100] }\end{array}$ & $\begin{array}{l}6 \text { months follow-up using } \\
\text { quinapril }\end{array}$ & $\begin{array}{l}\uparrow \text { total HRV and } \uparrow \text { parasym- } \\
\text { pathetic functions in the } \\
\text { early stages of DAN }\end{array}$ \\
\hline $\begin{array}{l}\text { Losartan } \\
\text { (ARB) and/or } \\
\text { Quinapril }\end{array}$ & $\begin{array}{l}\text { Patients with longstanding } \\
\text { DM (type } 1 \text { and } 2 \text { ) and DAN } \\
\text { [101] }\end{array}$ & $\begin{array}{l}12 \text { months of either or both } \\
\text { drugs }\end{array}$ & $\begin{array}{l}\uparrow \text { cardiac function with early } \\
\text { treatment using either of } \\
\text { both drugs; } \uparrow \text { efficacy with } \\
\text { combination therapy }\end{array}$ \\
\hline $\begin{array}{l}\text { Metoprolol } \\
\text { ( } \beta \text {-blocker) }\end{array}$ & $\begin{array}{l}\text { ACEl-treated type } 1 \text { DM pa- } \\
\text { tients with albuminuria [102] }\end{array}$ & 6 weeks of metoprolol & $\begin{array}{l}\uparrow \text { autonomic function ( } \uparrow \mathrm{HRV} \text { ) } \\
\text { upon addition of metoprolol } \\
\text { to treatment regimen }\end{array}$ \\
\hline $\begin{array}{l}\text { Atenolol } \\
\text { ( } \beta \text {-blocker) }\end{array}$ & $\begin{array}{l}\text { Type } 1 \text { DM patients with } \\
\downarrow \text { HRV and detectable } \\
\text { hs-CRP [103] }\end{array}$ & 3-4 weeks of atenolol & $\begin{array}{l}\uparrow \mathrm{HRV} \text { and } \uparrow \text { hs-CRP levels } \\
\text { in atenolol-treated patients }\end{array}$ \\
\hline $\begin{array}{l}\text { Epalrestat } \\
\text { (an ARI) }\end{array}$ & $\begin{array}{l}\text { Type } 2 \text { DM patients with } \\
\text { DAN [104] }\end{array}$ & 3 months or more & $\uparrow \mathrm{HRV}$ \\
\hline $\begin{array}{l}\text { ALA, } \\
\text { antioxidant }\end{array}$ & $\begin{array}{l}\text { Type } 2 \text { DM patients with } \\
\text { CAN }[105,106]\end{array}$ & 4 months of ALA & $\begin{array}{l}\text { Amelioration of CAN to } \\
\text { some degree }\end{array}$ \\
\hline $\begin{array}{l}\text { XNT (ACE2 } \\
\text { activator) }\end{array}$ & $\begin{array}{l}\text { STZ-induced diabetic rats } \\
\text { [107] }\end{array}$ & 30 days of XNT & $\begin{array}{l}\text { Protected against diabetes- } \\
\text {-induced cardiovascular } \\
\text { autonomic dysfunction }\end{array}$ \\
\hline $\begin{array}{l}\text { Vitamin E } \\
\text { (antioxidant) }\end{array}$ & Type 2 DM patients [108] & 4 months & $\begin{array}{l}\uparrow \text { cardiac sympathovagal } \\
\text { balance (as indicated by } \\
\uparrow \text { HRV parameters) on } \\
\text { long-term treatment }\end{array}$ \\
\hline \multirow[t]{2}{*}{$\begin{array}{l}\text { Physical } \\
\text { training } \\
\text { (exercise) }\end{array}$} & $\begin{array}{l}\text { DM patients with and } \\
\text { without CAN [109] }\end{array}$ & $\begin{array}{l}12 \text { weeks (of twice weekly } \\
\text { exercise of } 30 \text { min duration) }\end{array}$ & $\begin{array}{l}\uparrow \mathrm{HRV} \text { in patients without } \\
\text { CAN and in those with early } \\
\text { CAN but not in those with } \\
\text { advanced CAN; deterioration } \\
\text { of previously improved HRV } \\
\text { parameters following } \\
6 \text { weeks of exercise withdrawal }\end{array}$ \\
\hline & $\begin{array}{l}\text { Type } 2 \text { DM patients with } \\
\text { and without CAN [110] }\end{array}$ & $\begin{array}{l}6 \text { months (of thrice weekly } \\
\text { exercise) }\end{array}$ & $\begin{array}{l}\text { Improvement in some HRV } \\
\text { parameters in both groups } \\
\text { of patients with greater be- } \\
\text { nefits in those with definite } \\
\text { CAN; positive effects on lipid } \\
\text { profile, plasma glucose and } \\
\text { HbA1c in both groups }\end{array}$ \\
\hline
\end{tabular}

ACEI — angiotensin converting enzyme inhibitor; ACE2 - angiotensin converting enzyme 2; ALA — alpha-lipoic acid; ARB - angiotensin receptor blocker; ARI - aldose reductase inhibitor; CAN — cardiovascular autonomic neuropathy; DAN — diabetic autonomic neuropathy; DCCT — diabetes complication and control trial; DM - diabetes mellitus; HbA1c — glycated hemoglobin; hs-CRP - high sensitivity C-reactive protein; STZ — streptozotocin; XNT — 1-[(2-dimethylamino)ethylamino]-4-(hydroxymethyl)-7-[(4-methylphenyl) sulfonyl oxy]-9H-xanthene-9-one 
Pioglitazone [85] as a BRS-improving agent particularly appears to be useful in post-MI type 2 DM patients due to its cardioprotective functions. Breathing exercise [90] also appears to be useful in improving BRS in DM patients regardless of the duration (except of course in those with marked CAN). Alpha-lipoic acid (ALA) shows promise in potentially improving BRS in diabetic patients due to the results already obtained in experimental models [86]. ALA has also been shown to ameliorate CAN to some extent in type $2 \mathrm{DM}$ patients $[105,106]$. Statins (HMG-CoA reductase inhibitors) have proven to be a useful addition to treatment regimens in DM patients with co-existing cardiovascular risk factors [111]. Due to the beneficial effects of fluvastatin in improving BRS in STZ-induced diabetic rats [83], statins appears to be potentially useful in ameliorating baroreflex impairment in diabetic patients at both the medullary level (through their effects in up-regulating the expression of neuronal nitric oxide synthase, nNOS $[83,112]$ ) and at the baroreceptor level (through their effects in causing atherosclerotic plaque regression [113]). Leptin [87] still appears experimental at this stage; therefore there is need for more studies in order to ascertain its efficacy in improving BRS in diabetic patients. Perhaps the interventions listed in Table 3 may be more effective in improving BRS when they are combined together rather than when used individually; this hypothesis clearly warrants further studies in order to confirm if combination therapy (or multifactorial intervention) has these synergistic effects. There is also a need to further study these interventions (Table 3 ) in patients with depressed BRS that is accompanied by marked DAN to see if these interventions will still remain effective in improving BRS and in ameliorating the manifestations of autonomic neuropathy.

The pharmacological agents shown in Table 4 such as angiotensin converting enzyme inhibitors, angiotensin receptor blockers, beta-blockers, metformin, aldose reductase inhibitors, angiotensin converting enzyme-2 activators, etc., should also be further investigated in the context of their capability for improving BRS in diabetic patients.

Finally, there is a need for extensive follow-up studies in diabetic patients in order to determine if the gains (e.g. improved BRS and amelioration of cardiovascular autonomic dysfunction, etc.) obtained from the above mentioned interventions do translate into better clinical and prognostic outcomes (in terms of reduced cardiovascular morbidity and mortality) for such patients.

\section{Conclusions}

The key to success with diabetes and its complications is early diagnosis and immediate and ongoing treatment plans. With early diagnosis of baroreflex impairment in DM using the assessment methods outlined above and quick establishment of effective treatment plans, it is potentially possible to improve BRS and slow the progression of cardiovascular autonomic dysfunction in such patients.

\section{Acknowledgements}

This work was funded by a grant from the Polish Ministry of Higher Education and Science numbered 5808/B/T01/2010/38.

\section{Conflict of interest: none declared}

\section{References}

1. Guyton AC, Hall JE. Textbook of medical physiology. Elsevier Saunders, Philadelphia 2006: 204-215.

2. Boulpaep EL. Regulation of arterial pressure and cardiac output. In: Boron WF, Boulpaep EL eds. Medical physiology: A cellular and molecular approach. Updated ed. Elsevier Saunders, Philadelphia 2005: $534-557$.

3. Trzebski A. Fizjologia krazenia krwi. In: Traczyk WZ, Trzebski A eds: Fizjologia czlowieka $z$ elementami fizjologii stosowanej i klinicznej. (In the Polish language). Wydawnictwo Lekarskie PZWL, Warszawa 2004: 565-569.

4. La Rovere MT, Pinna GD, Raczak G. Baroreflex sensitivity: measurement and clinical implications. Ann Noninvasive Electrocardiol, 2008; 13: 191-207.

5. Kapa S, Somers VK. Cardiovascular manifestations of autonomic disorders. In: Libby P, Bonow RO, Mann DL eds. Braunwald's heart disease: a textbook of cardiovascular medicine. Saunders Elsevier, Philadelphia 2008: 2171-2183.

6. Vinik AI, Ziegler D. Diabetic cardiovascular autonomic neuropathy. Circulation, 2007; 115: 387-397.

7. Ponikowska B. Ocena regulacji odruchowych w ukladzie krazenia i oddychania u chorych $z$ cukrzyca typu 2 i choroba niedokrwienna serca. (In the Polish language). Akademia Medyczna we Wroclawiu, Wroclaw 2009: 1-178.

8. Davies LC, Colhoun H, Coats AJ, Piepoli M, Francis DP. A noninvasive measure of baroreflex sensitivity without blood pressure measurement. Am. Heart J, 2002; 143: 441-447.

9. Marfella R, Giugliano D, di Maro G, Acampora R, Giunta R, D’Onofrio F. The squatting test. A useful tool to assess both parasympathetic and sympathetic involvement of the cardiovascular autonomic neuropathy in diabetes. Diabetes, 1994; 43: 607-612.

10. Nakagawa M, Shinohara T, Anan F et al. New squatting test indices are useful for assessing baroreflex sensitivity in diabetes mellitus. Diabet Med, 2008; 25: 1309-1315.

11. Skrapari I, Tentolouris N, Katsilambros N. Baroreflex function: determinants in healthy subjects and disturbances in diabetes, obesity and metabolic syndrome. Curr Diab Rev, 2006; 2: 329-338.

12. Schobel HP, Oren RM, Roach PJ, Mark AL, Ferguson DW. Contrasting effects of digitalis and dobutamine on baroreflex sympathetic control in normal humans. Circulation, 1991; 84: 1118-1129.

13. Tank J, Jordan J, Diedrich A et al. Genetic influences on baroreflex function in normal twins. Hypertension, 2001; 37: 907-910.

14. Brooks VL, Cassaglia PA, Zhao D, Goldman RK. Baroreflex function in females: changes with the reproductive cycle and pregnancy. Gend Med., 2012; 9: 61-67.

15. Krapalis AF, Reiter J, Machleidt F et al. Ghrelin modulates baroreflex-regulation of sympathetic vasomotor tone in healthy humans. Am J Physiol Regul Integr Comp Physiol, 2012; 302: R1305-R1312. 
16. Chang KS, Lund DD. Alterations in the baroreceptor reflex control of heart rate in streptozotocin diabetic rats. J Mol Cell Cardiol. 1986; 18: 617-624.

17. Dall'Ago P, Fernandes TG, Machado UF, Belló AA, Irigoyen MC. Baroreflex and chemoreflex dysfunction in streptozotocin-diabetic rats. Braz J Med Biol Res, 1997; 30: 119-124.

18. Maeda CY, Fernandes TG, Timm HB, Irigoyen MC. Autonomic dysfunction in short-term experimental diabetes. Hypertension, 1995; 26: 1100-1104.

19. Frattola A, Parati G, Gamba P et al. Time and frequency domain estimates of spontaneous baroreflex sensitivity provide early detection of autonomic dysfunction in diabetes mellitus. Diabetologia, 1997; 40: 1470-1475.

20. Kaminska A, Tafil-Klawe M, Śmietanowski M et al. Spontaneous baroreflex sensitivity in subjects with type 1 diabetes with and without cardiovascular autonomic neuropathy. Endokrynol Pol, 2008; 59: 398-402.

21. Martiniskova Z, Kucera P, Sykora M, Kollar B, Goldenberg Z, Turcani P. Baroreflex sensitivity in patients with type I diabetes mellitus. NeuroEndocrinol Lett, 2009; 30: 491-495.

22. Fazan R Jr, Ballejo G, Salgado MC, Moraes MF, Salgado HC. Heart rate variability and baroreceptor function in chronic diabetic rats. Hypertension, 1997; 30: 632-635.

23. do Carmo JM, Huber DA, Castania JA, Fazan VP, Fazan R Jr, Salgado HC Aortic depressor nerve function examined in diabetic rats by means of two different approaches. J Neurosci Methods, 2007; 161: 17-22.

24. McDowell TS, Hajduczok G, Abboud FM, Chapleau MW. Baroreflex dysfunction in diabetes mellitus. II. Site of baroreflex impairment in diabetic rabbits. Am J Physiol, 1994; 266: H244-H249.

25. Huggett RJ, Scott EM, Gilbey SG, Bannister J, Mackintosh AF, Mary DA Disparity of autonomic control in type 2 diabetes mellitus. Diabetologia, 2005 ; 48: 172-179.

26. Bosch EP, Smith BE. Disorders of peripheral nerves. In: Bradley WG, Daroff RB, Fenichel GM eds. Neurology in clinical practice. Vol. 2. The neurological disorders. Butterworth-Heinemann, Woburn, MA, USA 2004: 2299-2401.

27. Schönauer M, Thomas A, Morbach S, Niebauer J, Schönauer U, Thiele H. Cardiac autonomic diabetic neuropathy. Diabetes Vasc Dis Res, 2008; 5: 336-344.

28. Vinik AI, Maser RE, Mitchell BD, Freeman R. Diabetic autonomic neuropathy. Diabetes Care, 2003; 26: 1553-1579.

29. Maser RE, Lenhard MJ. Cardiovascular autonomic neuropathy due to diabetes mellitus: clinical manifestations, consequences, and treatment. J Clin Endocrinol Metab, 2005; 90: 5896-5903.

30. Valensi P, Sachs RN, Harfouche B et al. Predictive value of cardiac autonomic neuropathy in diabetic patients with or without silent myocardial ischemia. Diabetes Care, 2001; 24: 339-343.

31. Ko SH, Song KH, Park SA et al. Cardiovascular autonomic dysfunction predicts acute ischaemic stroke in patients with type 2 diabetes mellitus: A 7-year follow-up study. Diabet Med, 2008; 25: 1171-1177.

32. Cohen JA, Estacio RO, Lundgren RA, Esler AL, Schrier RW. Diabetic autonomic neuropathy is associated with an increased incidence of strokes. Auton Neurosci, 2003; 108: 73-78.

33. Ewing DJ, Martyn CN, Young RJ, Clarke BF. The value of cardiovascular autonomic function tests: 10 years experience in diabetes. Diabetes Care, 1985; 8: 491-498.

34. Ziegler D, Laude D, Akila F, Elghozi JL. Time- and frequency-domain estimation of early diabetic cardiovascular autonomic neuropathy. Clin Auton Res, 2001; 11: 369-376.

35. Weston PJ, Panerai RB, McCullough A et al. Assessment of baroreceptor-cardiac reflex sensitivity using time domain analysis in patients with IDDM and the relation to left ventricular mass index. Diabetologia, 1996; 39: 1385-1391.

36. Salgado HC, Fazan Júnior R, Fazan VP, Da Silva VJ, Barreira AA. Arterial baroreceptors and experimental diabetes.Ann N Y Acad Sci, 2001; 940: 20-27.

37. Gouty S, Regalia J, Helke CJ. Attenuation of the afferent limb of the baroreceptor reflex in streptozotocin-induced diabetic rats. Auton Neurosci, 2001; 89: 86-95.

38. Gou YP. A pathologic study of the vagus nerves in diabetes mellitus. [Article in Chinese]. ZhonghuaShen Jing JingShenKeZaZhi, 1989; 22: 32-34.

39. Chen HY, Wu JS, Chen JJ, Cheng JT. Impaired regulation function in cardiovascular neurons of nucleus tractussolitarii in streptozotocin-induced diabetic rats. Neurosci Lett, 2008; 431: 161-166.

40. Yan B, Li L, Harden SW, Wurster RD, Cheng ZJ. Diabetes induces neural degeneration in nucleus ambiguus (NA) and attenuates heart rate control in OVE26 mice. ExpNeurol, 2009; 220: 34-43.

41. Maitra A, Abbas AK. The endocrine system. In: Kumar V, Abbas AK, Fausto N eds. Robbins and Cotran pathologic basis of disease. Elsevier Saunders, Philadelphia 2005: 1155-1226.
42. Schneider AS, Szanto PA. Vascular system. In: Schneider AS, Szanto PA eds. Board review series pathology. Lippincott Williams \& Wilkins, Philadelphia 2006: 123-136.

43. Gianaros PJ, Jennings JR, Olafsson GB et al. Greater intima-media thickness in the carotid bulb is associated with reduced baroreflex sensitivity. Am J Hypertens, 2002; 15: 486-491.

44. Nasr N, Pavy-Le Traon A, Larrue V. Baroreflex sensitivity is impaired in bilateral carotid atherosclerosis. Stroke, 2005; 36: 1891-1895.

45. Yakhou L, Constant I, Merle JC, Laude D, Becquemin JP, Duvaldestin P. Noninvasive investigation of autonomic activity after carotid stenting or carotid endarterectomy. J Vasc Surg, 2006; 44: 472-479.

46. Acampa M, Guideri F, Marotta G et al. Autonomic activity and baroreflex sensitivity in patients submitted to carotid stenting. Neurosci Lett, 2011; 491: 221-226.

47. Gottsäter A, Rydén-Ahlgren A, Szelag B et al. Cardiovascular autonomic neuropathy associated with carotid atherosclerosis in type 2 diabetic patients. Diabet Med, 2003; 20: 495-499.

48. Clarke JA, Daly Mde B, Ead HW, Hennessy EM. The carotid body of the spontaneous insulin-dependent diabetic rat. Braz J Med.Biol Res, 1999; 32: 85-91.

49. Fazan VP, Salgado HC, Barreira AA. Aortic depressor nerve myelinated fibers in acute and chronic experimental diabetes. Am J Hypertens, 2006; 19: 153-160.

50. Li YL. Elevated angiotensin II in rat nodose ganglia primes diabetes-blunted arterial baroreflex sensitivity: involvement of NADPH oxidase-derived superoxide. J Diabetes Metab, 2011; 2. pii: 1000135.

51. Li YL, Zheng H. Angiotensin II-NADPH oxidase-derived superoxide mediates diabetes-attenuatedcell excitability of aortic baroreceptor neurons. Am J Physiol Cell Physiol, 2011; 301: x1368-x1377.

52. Li YL, Tran TP, Muelleman R, Schultz HD. Blunted excitability of aortic baroreceptor neurons in diabetic rats: involvement of hyperpolarization-activated channel. Cardiovasc Res, 2008; 79: 715-721.

53. Eckberg DL, Harkins SW, Fritsch JM, Musgrave GE, Gardner DF. Baroreflex control of plasma norepinephrine and heart period in healthy subjects and diabetic patients. J Clin Invest, 1986; 78: 366-374.

54. Anan F, Takahashi N, Nakagawa M, Ooie T, Saikawa T, Yoshimatsu H. High-sensitivity C-reactive protein is associated with insulin resistance and cardiovascular autonomic dysfunction in type 2 diabetic patients. Metabolism, 2005; 54: 552-558.

55. Llauradó G, Gallart L, Tirado R et al. Insulin resistance, low-grade inflammation and type 1 diabetes mellitus. Acta Diabetol, 2012; 49: 33-39.

56. Wu DM, Chu NF, Shen MH, Wang SC. Obesity, plasma high sensitivity $\mathrm{C}$-reactive protein levels and insulin resistance status among school children in Taiwan. Clin Biochem, 2006; 39: 810-815.

57. Yang SP, Gong CX, Cao BY, Yan C. Relationship between serum high-sensitivity C-reactive protein and obesity and impaired glycose metabolism in children and adolescents. [Article in Chinese]. Zhonghua Er Ke Za Zhi, 2006; 44: 933-936.

58. Takahashi N, Anan F, Nakagawa M et al. Microalbuminuria, cardiovascular autonomic dysfunction, and insulin resistance in patients with type 2 diabetes mellitus. Metabolism, 2004; 53: 1359-1364.

59. Takahashi N, Nakagawa M, Saikawa T et al. Effect of essential hypertension on cardiac autonomic function in type 2 diabetic patients. J Am Coll Cardiol, 2001; 38: 232-237.

60. Takahashi N, Anan F, Nakagawa M et al. Hypoadiponectinemia in type 2 diabetes mellitus in men is associated with sympathetic overactivity as evaluated by cardiac 123I-metaiodobenzylguanidine scintigraphy. Metabolism, 2007; 56: 919-924.

61. Muntzel MS, Anderson EA, Johnson AK, Mark AL. Mechanisms of insulinaction on sympathetic nerve activity. Clin Exp Hypertens, 1995; 17: 39-50

62. Bellavere F, Cacciatori V, Moghetti P et al. Acute effect of insulin on autonomic regulation of the cardiovascular system: a study by heart rate spectral analysis. Diabet Med, 1996; 13: 709-714.

63. Epstein M. Diabetes and hypertension: The bad companions. J Hypertens Suppl, 1997; 15: 55-62.

64. Weston PJ, James MA, PaneraiRB, McNally PG, Potter JF, Thurston H. Evidence of defective cardiovascular regulation in insulin-dependent diabetic patients without clinical autonomic dysfunction. Diabetes Res Clin Pract, 1998; 42: 141-148.

65. Ferrannini E, Cushman WC. Diabetes and hypertension: the bad companions. Lancet, 2012; 380: 601-610.

66. Lefrandt JD, Hoogenberg K, van Roon AM, Dullaart RP, Gans RO, Smit AJ. Baroreflex sensitivity is depressed in microalbuminuric type diabetic patients at rest and during sympathetic manoeuvres. Diabetologia, 1999; 42: 1345-1349.

67. Moran A, Palmas W, Field L et al. Cardiovascular autonomic neuropathy is associated with microalbuminuria in older patients with type 2 diabetes. Diabetes Care, 2004; 27: 972-977. 
68. Gerstein HC, Mann JF, Yi Q et al. Albuminuria and risk of cardiovascular events, death, and heart failure in diabetic and nondiabetic individuals. JAMA, 2001; 286: 421-426.

69. Díez JJ, Iglesias P. The role of the novel adipocyte-derived hormone adiponectin in human disease. Eur J Endocrinol, 2003; 148: 293-300.

70. Kojima S, Funahashi T, Maruyoshi $\mathrm{H}$ et al. Levels of the adipocyte-derived plasma protein, adiponectin, have a close relationship with atheroma. Thromb Res, 2005; 115: 483-490.

71. Díez JJ, Iglesias P. The_role_of the novel_adipocyte-derived_protein adiponectin in human disease: An update. Mini Rev Med Chem, 2010; 10: 856-869.

72. Yufu K, Takahashi N, Nakagawa M et al. Brain natriuretic peptide and cardiac autonomic function in type 2 diabetic patients. Diabetes Res Clin Pract, 2006; 72: 12-19.

73. Dawson A, Struthers AD. Screening for treatable left ventricular abnormalities in diabetic patients. Expert Opin Biol Ther, 2003; 3: 107-112.

74. Weston PJ, Panerai RB, McCullough A et al. Assessment of baroreceptor-cardiac reflex sensitivity using time domain analysis in patients with IDDM and the relation to left ventricular mass index. Diabetologia, 1996; 39: 1385-1391.

75. Bhalla MA, Chiang A, Epshteyn VA et al. Prognostic role of B-type natriuretic peptide levels in patients with type 2 diabetes mellitus. J Am Coll Cardiol, 2004; 44: 1047-1052.

76. Okada N, Takahashi N, Yufu K et al. Baroreflex sensitivity predicts cardiovascular events in patients with type 2 diabetes mellitus without structural heart disease. Circ J, 2010; 74: 1379-1383.

77. Billman GE, Schwartz PJ, Stone HL. Baroreceptor reflex control of heart rate: a predictor of sudden cardiac death. Circulation, 1982; 66: 874-880.

78. La Rovere MT, Bigger JT Jr, Marcus FI, Mortara A, Schwartz PJ. Baroreflex sensitivity and heart-rate variability in prediction of total cardiac mortality after myocardial infarction. ATRAMI (Autonomic Tone and Reflexes After Myocardial Infarction) Investigators. Lancet, 1998; 351: 478-484.

79. De Ferrari GM, Sanzo A, Bertoletti A, Specchia G, Vanoli E, Schwartz PJ. Baroreflex sensitivity predicts long-term cardiovascular mortality after myocardial infarction even in patients with preserved left ventricular function. J Am Coll Cardiol, 2007; 50: 2285-2290.

80. Gerritsen J, Dekker JM, TenVoorde BJ et al. Impaired autonomic function is associated with increased mortality, especially in subjects with diabetes, hypertension, or a history of cardiovascular disease: The Hoorn Study. Diabetes Care, 2001; 24: 1793-1798.

81. Yufu K, Takahashi N, Okada N et al. Gender difference in baroreflex sensitivity to predict cardiac and cerebrovascular events in type 2 diabetic patients. Circ J, 2011; 75: 1418-1423.

82. DallaPozza R, Bechtold S, Bonfig W et al. Impaired short-term blood pressure regulation and autonomic dysbalance in children with type 1 diabetes mellitus. Diabetologia, 2007; 50: 2417-2423.

83. Schwartz PJ, Vanoli E, Stramba-Badiale M, De Ferrari GM, Billman GE, Foreman RD. Autonomic mechanisms and sudden death. New insights from analysis of baroreceptor reflexes in conscious dogs with and without a myocardial infarction. Circulation, 1988;78: 969-979.

84. Powers AC. Diabetes mellitus. In: Longo DL, Fauci AS, Kasper DL eds. Harrison's principles of internal medicine. McGraw-Hill Medical, New York 2011: 2968-3003.

85. Yokoe H, Yuasa F, Yuyama R et al. Effect of pioglitazone on arterial baroreflex sensitivity and sympathetic nerve activity in patients with acute myocardial infarction and type 2 diabetes mellitus. J Cardiovasc Pharmacol, 2012; 59: 563-569.

86. Gouty S, Regalia J, Cai F, Helke CJ. Alpha-lipoic acid treatment prevents the diabetes-induced attenuation of the afferent limb of the baroreceptor reflex in rats. Auton Neurosci, 2003; 108: 32-44.

87. do Carmo JM, Hall JE, da Silva AA. Chronic central leptin infusion restores cardiac sympathetic-vagal balance and baroreflex sensitivity in diabetic rats. Am J Physiol Heart Circ Physiol, 2008; 295: H1974-H1981.

88. Xie F, Sun C, Sun LH et al. Influence of fluvastatin on cardiac function and baroreflex sensitivity in diabetic rats. Acta Pharmacol Sin, 2011; 32: $321-328$.

89. Frattola A, Parati G, Castiglioni P et al. Lacidipine and blood pressure variability in diabetic hypertensive patients. Hypertension, 2000; 36: 622-628.

90. Rosengård-Bärlund M, Bernardi L, Holmqvist J et al. FinnDiane Study Group. Deep breathing improves blunted baroreflex sensitivity even after 30 years of type 1 diabetes. Diabetologia, 2011; 54: 1862-1870.

91. Jorge L, da Pureza DY, da Silva Dias D, Conti FF, Irigoyen MC, De Angelis K. Dynamic aerobic exercise induces baroreflex improvement in diabetic rats. Exp Diabetes Res, 2012; 2012: 108680.

92. Harthmann AD, De Angelis K, Costa LP et al. Exercise training improves arterial baro- and chemoreflex in control and diabeticrats. Auton Neurosci, 2007; 133: 115-120.
93. Loimaala A, Huikuri HV, Kööbi T, Rinne M, Nenonen A, Vuori I. Exercise training improves baroreflex sensitivity in type 2 diabetes. Diabetes, 2003; 52: 1837-1842.

94. Madden KM, Lockhart C, Potter TF, Cuff D. Aerobic training restores arterial baroreflex sensitivity in older adults with type 2 diabetes, hypertension, and hypercholesterolemia. Clin J Sport Med, 2010; 20: 312-317.

95. Schnell O, Kilinc S, Rambeck A, Standl E. Insulin therapy improves cardiac autonomic function in type 2 diabetic patients. [Article in German]. Herz, 2004; 29: 519-523.

96. Burger AJ, Weinrauch LA, D'Elia JA, Aronson D. Effect of glycemic control on heart rate variability in type I diabetic patients with cardiac autonomic neuropathy. Am J Cardiol, 1999; 84: 687-691.

97. The Diabetes Control and Complications Trial Research Group. The effect of intensive treatment of diabetes on the development and progression of long-term complications in insulin-dependent diabetes mellitus. N Engl J Med, 1993; 329: 977-986.

98. Pop-Busui R, Low PA, Waberski BH et al. Effects of prior intensive insulin therapy on cardiac autonomic nervous system function in type 1 diabetes mellitus: The Diabetes Control and Complications Trial/Epidemiology of Diabetes Interventions and Complications study (DCCT/ /EDIC).Circulation, 2009; 119: 2886-2893.

99. Manzella D, Grella R, Esposito K, Giugliano D, Barbagallo M, Paolisso G. Blood pressure and cardiac autonomic nervous system in obese type 2 diabetic patients: Effect of metformin administration. Am J Hypertens, 2004; 17: 223-227.

100. Kontopoulos AG, Athyros VG, Didangelos TP et al. Effect of chronic quinapril administration on heart rate variability in patients with diabetic autonomic neuropathy. Diabetes Care, 1997; 20: 355-361.

101. Didangelos TP, Arsos GA, Karamitsos DT, Athyros VG, Georga SD, Karatzas ND. Effect of quinapril or losartan alone and in combination on left ventricular systolic and diastolic functions in asymptomatic patients with diabetic autonomic neuropathy. J Diabetes Compl, 2006; 20: $1-7$.

102. Ebbehoj E, Poulsen PL, Hansen KW, Knudsen ST, Mølgaard H, Mogensen CE. Effects on heart rate variability of metoprolol supplementary to ongoing ACE-inhibitor treatment in Type I diabetic patients with abnormal albuminuria. Diabetologia, 2002; 45: 965-975.

103. Lanza GA, Pitocco D, Navarese EP et al. Association between cardiac autonomic dysfunction and inflammation in type 1 diabetic patients: Effect of beta-blockade. Eur Heart J, 2007; 28: 814-820.

104. Okamoto H, Nomura M, Nakaya Y et al. Effects of epalrestat, an aldose reductase inhibitor, on diabetic neuropathy and gastroparesis. Intern Med, 2003; 42: 655-664.

105. Ziegler D, Schatz H, Conrad F, Gries FA, Ulrich H, Reichel G. Effects of treatment with the antioxidant alpha-lipoic acid on cardiac autonomic neuropathy in NIDDM patients. A 4-month randomized controlled multicenter trial (DEKAN Study). Deutsche Kardiale Autonome Neuropathie. Diabetes Care, 1997; 20: 369-373.

106. Ziegler D, Gries FA. Alpha-lipoic acid in the treatment of diabetic peripheral and cardiac autonomic neuropathy. Diabetes, 1997; 46 (suppl. 2): S62-S66.

107. Murça TM, Almeida TC, Raizada MK, Ferreira AJ. Chronic activation of endogenous angiotensin-converting enzyme 2 protects diabetic rats from cardiovascular autonomic dysfunction. Exp Physiol, 2012; 97: 699-709.

108. Manzella DD, Barbieri M, Ragno E, Paolisso G. Chronic administration of pharmacologic doses of vitamin $\mathrm{E}$ improves the cardiac autonomic nervous system in patients with type 2 diabetes. Am J Clin Nutr, 2001; 73: 1052-1057.

109. Howorka K, Pumprla J, Haber P, Koller-Strametz J, Mondrzyk J, Schabmann A. Effects of physical training on heart rate variability in diabetic patients with various degrees of cardiovascular autonomic neuropathy. Cardiovasc Res, 1997; 34: 206-214.

110. Pagkalos M, Koutlianos N, Kouidi E, Pagkalos E, Mandroukas K, Deligiannis A. Heart rate variability modifications following exercise training in type 2 diabetic patients with definite cardiac autonomic neuropathy. Br J Sports Med, 2008; 42: 47-54.

111. Ponikowska B, Jankowska EA, Reczuch K et al. Abnormal indices of autonomic function are no longer predictors of poor outcome in diabetic patients without neuropathy but with coexisting coronary artery disease who receive optimal pharmacological therapy. Kardiol Pol, 2009; 67: 1325-1332.

112. Gao L, Wang W, Zucker IH. Simvastatin inhibits central sympathetic outflow in heart failure by a nitric-oxide synthase mechanism. J Pharmacol Exp Ther, 2008; 326: 278-285.

113. Sachar R, Yadav JS. Carotid artery disease. In: Griffin BP, Topol EJ eds. Manual of cardiovascular medicine. Lippincott William and Wilkins, Philadelphia 2004: 404-418. 